Abeer Aly El Attar

\title{
The Representation of Social Actors in Jacinda Ardern's Parliamentary Speech: A Critical Discourse Analysis of New Zealand Mosque Massacre
}

\author{
Abeer Aly El Attar \\ Faculty of Al-Alsun, Ain Shams University
}

\begin{abstract}
On the $15^{\text {th }}$ of March 2019, the world witnessed Christchurch Muslim massacre in New Zealand which took the lives of 50 Muslims and left many injured. The study adopts a critical discourse approach to account for such massacre. Adopting critical discourse analysis as an approach serves to investigate the interrelationship between language and ideology. Working within the theoretical framework of van Dijk's $(1997,1998,2006,2009,2011)$ concept of ideological square and van Leeuwen's (2008) socio-semantic approach as an analytical framework, the study accounts for the representation of social actors in addition to the presentation of 'self' and 'other' in the parliamentary speech of Jacinda Ardern, New Zealand's Prime Minister. The study also attends to the representation of the identities of the social actors and the ideology underpinning Arden's parliamentary speech. The results of the analysis reveal that the social actors were differently represented in Ardern's speech, so as to suit her ideological stance. The study concludes that Muslims are positively presented as "other"; the perpetrator is negatively presented as "other"; and New Zealanders (incorporating Ardern, official bodies, and people) are positively presented as 'self'. The ideology underpinning her speech reveals her rejection of the perpetrator's racist stance and ideology; acceptance of the other, and an anti-racist stance against Muslims.
\end{abstract}

Key words: representation, social actors, ideology, critical discourse analysis, self and other

\section{Introduction}

With the influx of many Muslims, as immigrants, or refugees, or for any other reason, from their homeland to other foreign countries, several problems arise. They can either find acceptance or face rejection by the hosting communities, exemplified in hate crimes, racism and other problems. Muslims in New Zealand were targeted by an Australian citizen, who shot dead and injured worshippers on account of his racist ideology. Adopting critical discourse analysis as an approach in examining the linguistic features of politicians' speeches serves in disclosing hidden ideologies. The Prime Minister of New Zealand, Jacinda Ardern, a politician, is conveying the message that the perpetrator of the terrorist act is not like "us" people of New Zealand. van Leeuwen (2008) pinpoints strategies for representing social actors, identities and the ideological impact of such classification. The representational strategies serve to position participants in the social world and highlight 
or hide aspects of their identities. As a politician she has a range of choices available to her, to select and decide how to represent self and other.

\subsection{Aim of Study}

Working within the framework of critical discourse analysis, the study scrutinizes linguistic features of the text to uncover representations of the social actor from the perspective of a high status politician, Prime Minister, Jacinda Ardern. Moreover, the study examines how such representational strategies are neatly tailored to uncover the ideological polarization of 'Us' versus 'them'. For that reason, the study attempts to provide answers to the following questions:

1) How are the identities of the social actors represented in Ardern's parliamentary speech?

2) How does Arden's parliamentary speech account for the representation of self and other?

3) What is the ideological impact of this speech?

\section{Literature Review}

Several studies adopt CDA as a framework of analysis using different tools of analysis such as the representation of social actors or the presentation of self and other. Ashmawi (2011) works within the framework of CDA to examine the relationship between language and ideology in a novel entitled Terrorist. She explores the representation of Muslims in the novel after the 9/11 crisis using SFG and van Dijk's strategy of the 'Self' and the "Other". She concludes, from the representation of the characters, that the novelist is not against Islam.

Bernard (2018) draws on CDA as an analytical approach. The study adopts van Leeuwen's (2008) socio-semantic framework of the representation of social actors to examine how two South African companies construct the identities of their employees in their annual reports. The study concludes that both companies reflect their acquisition of positive human qualities through the use of metaphors; employees are constructed in a generic way. Both companies employ fixed strategies to represent their employees.

Dashti and Mehrpour (2017) apply van Leeuwen's (1996) morphosyntactic model to analyze the representation of social actors in the lectures of two philosophers: Krishnamurti and Watts. The study concludes that the social actors are presented differently. 


\section{Abeer Aly El Attar}

In another study, Rashidi and Rasti (2012) adopt van Leeuwen's (1996) model for the representation of social actors in the news reports of four Western quality papers related to the topic of imposing or tightening sanctions on Iran. The study concludes that different representational strategies were used to refer to the social actors representing the Western camp and the Iranian government on the issue of the sanctions. The paper reflects the ideological bias in representing the Iranian side.

Working within the framework of critical discourse analysis, Sahragard and Davatgarzadeh (2010) adopt van Leeuwen's (1996) model to account for the linguistic representation of male and female social actors and the construction of their identities in the Interchange Third Edition. The study applies Halliday and Matthiessen's (2004) model of transitivity. The study concludes that gender differences are reflected in the representation of social actors: females are represented as more prominent, active, independent, and expressive than the males.

This paper attempts to fill a gap in previous studies by adopting van Leeuwen's sociosemantic inventory and van Dijk's concept of ideological square to examine the representation of social actors, self and otherpresentation and uncover hidden ideologies in the parliamentary speech of Jacinda Ardern.

\section{Theoretical Background}

\subsection{Critical Discourse Analysis (CDA)}

Critical discourse analysis as a field of study creates an interrelationship between language, power and ideology, as Fairclough (1989) maintains. CDA assumes that power relations are discursive; they are "exercised and negotiated in discourse" (Fairclough\& Wodak,1997, p. 272).

Fairclough, Mulderrig and Wodak (2011) maintain that CDA examines the relationship between language and society. For that reason, Fairclough (1989) explains that language "is socially shaped by society, but it is also socially shaping, or constitutive" (p.131). Similarly, Machin and Mayr (2012) describe language as "a means of social construction" (p.4). CDA discloses ideologies which could "shape the representation of events and persons for particular ends" (Machin\& Mayr, 2012, p.5).

This study adopts critical discourse analysis as an approach to account for the interplay between language and ideology in relation to an ongoing political and social event to reach a better understanding. CDA sets to clarify the ideological underpinnings, which may not be noticed or recognized by readers, viewers, or people in general. 
The Representation of Social Actors in Jacinda Ardern's Parliamentary

Speech: A Critical Discourse Analysis of New Zealand Mosque Massacre

\subsection{Van Leeuwen's (2008) Sociosemantic Framework}

van Leeuwen's (2008) socio-semantic approach offers a comprehensive discursive framework to account for the ways social actors (participants) are represented in the different social practices (i.e. what people do). He simply defines social practices as "socially regulated ways of doing things" (p.6). This study attempts to account for the ways social actors are represented in Ardern's parliamentary speech. Such representations could reveal hidden ideologies and construct identities.

van Leeuwen's (2008) framework draws up on sociosemantic categories rather than grammatical categories, yet he maintains that the representation of social actors is linguistically based. Within such framework, social actors, as an element of the social practice, can be excluded or included for ideological reasons through some representational strategies. In his socio-semantic approach, van Leeuwen's (2008) proposes ten categories to examine linguistic features and discursive practices implied in texts. He presents a dichotomy between inclusion and exclusion stressing that some texts exclude or include social actors for certain purposes.

\subsubsection{Exclusion}

van Leeuwen (2008) describes inclusion as "an important aspect of critical discourse analysis" (p. 38). It is subdivided into: suppression and backgrounding. Suppression means "no reference to the social actor(s) and their activities" (p.37). In backgrounding, the less radical type of exclusion, the excluded social actors may appear later in the text and can be inferred. The social actors are "de-emphasized, pushed into the background" (p.29). Suppression can be realized in four different ways:

1. Agentless passive voice (e.g., Funeral costs are covered)

2. Non-finite clauses such as infinitival clauses (e.g. to maintain this policy is hard)

3. Nominalizations and process nouns (e.g., the arrest was an act of bravery)

4. Certain adjectives. (Refugees are deprived of legitimate rights)

Backgrounding is realized by simple ellipsis in nonfinite clauses withing and -ed participles, infinitival clauses with to, and in paratactic clauses. 


\subsubsection{Inclusion \\ Role allocation:}

This refers to the roles assigned to social actors in the representations. Social actors may be represented as active forces through the process of Activation or they may be Subjected or Beneficialized through the process of Passivation. Activation may be realized by grammatical participant roles, by transitivity structures, prepositional circumstantial (by or from), premodification (e.g. public transport) and postmodification (e.g. the influx of Syrians) of nominalizations. In passivation, subjected social actors are like commodities or things that can be bought or sold or exchanged (e.g., the issue of bringing in immigrant workers is more complicated). On the other hand, beneficialised social actors are other people or parties who benefit from an activity (e.g. The Syrian immigrants arrived, bringing cheap labor force to the factories in Germany. Subjection is realized by participation in terms of the passivated social actor functioning as the goal in material process, phenomenon in a mental process, or carrier in an attributive process.

\section{Genericization and Specification}

van Leeuwen draws the attention to the choice between generic and specific representation of social actors. In this category, social actors are referred to as part of a class of people (genericised), or referred to as identifiable individuals (specified). Genericization is realized by plural without an article (non- European immigrants), the singular with the definite article (the child), singular with an indefinite article (e.g., a man), and mass noun without articles (e.g., police). Specification is realized by a numerative or by mass nouns provided that the verb is not in the present tense (e.g., staff in nurseries expressed concern about hygienic measures)

\section{Assimilation}

Social actors can also be individualized, or represented as groups, in a process termed assimilation (this nation, the community). Assimilation has two subtypes: aggregation and collectivisation. Aggregation refers to social actors in terms of definite or indefinite quantifiers (e.g., many Egyptians, a number of students) and statistics (e.g., twenty percent of Egyptians), while collectivisation does not represent social actors in terms of statistics (we, experts, immigrants, New Zealand).

\section{Association and Dissociation}

Under this strategy, social actors can also be represented as formed groups or unformed groups. Association refers to groups formed by 
The Representation of Social Actors in Jacinda Ardern's Parliamentary

Speech: A Critical Discourse Analysis of New Zealand Mosque Massacre

social actors, which are never labelled in the text, yet may be referred to. Dissociation refers to unformed association, which means that a text associates the social actors in the beginning and dissociates them later.

\section{Indetermination and Differentiation}

Indetermination occurs when social actors' identities are unspecified or anonymous.It is realized by indefinite pronouns ('someone'), by generalized exophoric reference. Differentiation tends to differentiate between a social actor or a group of social actors and a similar actor or group. Consequently, marking the polarization between the self and the other or 'us' versus 'them'.(p.40)

\section{Nomination and Categorization}

Social actors may be nominated, represented in terms of their unique identity. This can be realized by proper nouns which can be formal (Mr. Brown), semi- formal (Mona Baker), or informal (Susan). All nominations can be vocatives. Social actors can be categorized in terms of the identities or functions they share with others (p.42).

\section{Functionalization and identification}

Categorization is subdivided into functionalisation and identification. Functionalization represents social actors in terms of what they do (i.e., occupation or role), while identification represents social actors in terms of what they are. Functionalization is achieved in terms of adding a suffix (-er, -ant, -ent, -ee, -ent) to a verb to form a noun (interviewer, responder), or by adding a suffix to a noun that denotes a tool or a place (mountaineer, pianist), or by compounding nouns that refer to places or tools (cameraman, chairperson). Identification is subdivided into: classification, where social actors socially classified in terms of race, age, gender, religion, provenance etc.; relational identification, which represents social actors in terms of their personal, kinship or work relations to each other (i.e. 'aunt' or 'friend'); and physical identification, identifies the participants in terms of physical characteristics (cripple) and attribute (bearded) which often have connotations (p.43). 


\section{Abeer Aly El Attar}

\section{Personalization and Impersonalization}

Personalization can refer to social actors as human beings. It is realized by personal pronouns, possessive pronouns, proper names, nouns and adjectives (having a human feature). Impersonalization is subdivided into two categories: abstraction and objectivation. "Abstraction refers to social actor by means of a quality assigned to them. Objectivation represents social actors in terms of a place or thing closely associated with them or their activity. Objectiviation is subdivided into four types: spatialisation, utterance autonomisation, instrumentalisation, and somatisation.

1) Spatialisation indicates the place with which social actors are closely associated (e.g., New Zealand opens its door to immigrants).

2) Instrumentalisation indicates the instrument with which social actors carry out an activity.

(e.g., A $120 \mathrm{~mm}$ mortar shell destroyed the area

3) Utterance autonomisation, refers to the social actors in terms of their utterance (e.g. the report noted)

4) Somatization represents social actors in terms of their body parts (her hand, his shoulder)

\section{Overdetermination}

It is a strategy through which social actors are represented as participants in more than once social practice, at the same time. Overdetermination is subdivided into: inversion, symbolization, connotation, and distillation they are not applicable to this study.

\subsection{Van Dijk's Concept of ideological Square}

Wodak (2009) discusses three basic concepts in CDA: "the concept of power, the concept of history, and the concept of ideology" (p.3). van Dijk (2006) defines ideology as "some kind of 'ideas', that is, belief systems" (p.116); such belief systems "underlie and organize the shared social representations of groups and their members" (van Dijk,1997, p.17). Fairclough, Mulderrig and Wodak (2011) stress the role ideologies play in representing and building societies whereby they create inequalities of power relations. van $\operatorname{Dijk}(2006)$ clarifies that ideologies incorporate social representations through which a group's social identity is defined. The representation of group relations is an essential aspect of ideology. van Dijk $(1997,1998,2005,2006,2009,2011)$ tackles the concept of ideological square which focuses on the in-group/ out-group polarization ('us' versus 'them'). The Ideological square, incorporates four complementary meta-strategies which delineate the features of 
The Representation of Social Actors in Jacinda Ardern's Parliamentary

Speech: A Critical Discourse Analysis of New Zealand Mosque Massacre

positive self- presentation (i.e., face-keeping) (van Dijk,1998) and negative other-presentation. Self can be "the individual speaker or an institution or social group the speaker identifies with" (Hart, 2016, p.7). This ideological square emphasizes the positive things about 'Us' and deemphasizes the negative things about 'Us'; similarly, it emphasizes the negative things about 'Them' and de-emphasizes the positive things about 'Them'.

Politicians manipulate the ideological square to their advantage by emphasizing positive aspects about themselves and their own group which incorporates their nation party and ideology, as van Dijk (1997) postulates. Politicians emphasize positive things about themselves and their group using linguistic devices such as lexicon, syntax and rhetoric (van Dijk, 2006). One of the syntactic tools is the manipulation of pronouns. Meyer (2009) stresses the importance of pronouns in CDA. Chilton and Schäffner(2011) clarify that politicians use the pronouns we/us/our/ours to align themselves ,their parties, their nation as one group. Similarly, van Dijk (2006) and Wilson (2015) maintain that politicians manipulate pronouns in order to mark a distinction between "them" and "us" (p.779)

Table 1. Self and Other-presentation

\begin{tabular}{|l|l|}
\hline $\begin{array}{l}\text { 'Us' Positive Self- } \\
\text { Presentation }\end{array}$ & $\begin{array}{l}\text { 'Them' Negative Other - } \\
\text { Presentation }\end{array}$ \\
\hline $\begin{array}{l}\text { Emphasize positive things about } \\
\text { 'us'/our good things }\end{array}$ & $\begin{array}{l}\text { emphasize negative things about } \\
\text { 'them'/ Their bad things }\end{array}$ \\
\hline $\begin{array}{l}\text { De-emphasize negative things } \\
\text { about 'us'/ our bad things }\end{array}$ & $\begin{array}{l}\text { De-emphasize positive things } \\
\text { about 'them'/Their good things }\end{array}$ \\
\hline
\end{tabular}

Based on van Dijk's (2011) model of self and other presentation

CDA attends to the relationship between language and ideology. Ideologies position people and societies in polarized ways either as 'Us' or 'them'. The strategy of positive self-representation and negative otherpresentation can reveal hidden ideologies.

\section{Methodology}

The study adopts a CDA qualitative approach to analyze the representation of social actors to uncover some aspects of identities and reveal underpinning ideologies. The study draws on van Leeuwen's (2008) socio- semantic framework to account for the representation of social actors and the ways their identities are constructed. The study equally examines the representation of self and other as implied by van Dijk's concept of ideological square. 


\subsection{Sources of data}

On the $15^{\text {th }}$ of March 2019, an Australian citizen attacked two mosques in Christchurch, New Zealand, killing 51 and injuring 49 Muslims. The attack was broadcast live on Facebook as the perpetrator livestreamed himself killing the worshippers. In the wake of the attack, New Zealand Prime minister, Jacinda Ardern addresses the parliament on the $19^{\text {th }}$ of March 2019. Her parliamentary speech on Tuesday March 19 is retrievable from the website of New Zealand television at www.tvnz.co.nz

\subsection{Procedure of analysis}

The parliamentary speech is downloaded as a sequence of utterances. For ease of analysis the utterances are numbered; the number is provided after each example. The analysis examines Arden's speech (68 utterances) in terms of van Leeuwen's (2008) taxonomy of social actor representation, hence revealing their identities. Then the analysis examines the representation of self and other according to van Dijk's concept of ideological square. Finally, the analysis sheds the light upon the underlying ideologies.

\section{Analysis}

In her attempt to prove that all New Zealand residents' religious and cultural beliefs are respected, Ardern inaugurates her parliamentary speech with an Islamic greeting "Al Salam Alaikum". As a politician, she expresses her solidarity and alignment with the Muslim community. Moreover, Ardern can select and decide how to represent her social actors from a range of choices available to her. Ardern's representational strategies tend to position social actors as in-group (self) or out-group (other) and to underline or conceal aspects of identity.

\section{1. van Leeuwen's (2008) framework of Social Actors}

\subsubsection{Exclusion}

Representations can include or exclude social actors. Exclusion is an important aspect in CDA. Exclusions can be radical excluding social actors and their activities likewise. Exclusion is subdivided into suppression and backgrounding : suppression does not refer to the social actor in the text; backgrounding is less radical exclusion; social actors are de-emphasized (i.e. pushed into the background). In her speech, Ardern can suppress or background social actors according to her ideological purpose.

Suppression can be achieved by passive agent deletion. In handling the crisis, Ardern proves to be a competent politician. By using agentless passive structures, her focus is on pinpointing the measures taken and the solutions. The agent or the social actor is easily inferred and could be retrieved from the speech. The government or the 'official 
The Representation of Social Actors in Jacinda Ardern's Parliamentary

Speech: A Critical Discourse Analysis of New Zealand Mosque Massacre

bodies' and Ardern as a prime minister are responsible for executing all measures and action, which reflects a sense of control.

- $\quad$ There is a huge focus on ensuring the needs of families are met. (28)

- A community welfare centre has been set up near the hospital in Christchurch to make sure people know how to access support (28)

- Visas for family members are being prioritized. Funeral costs are covered (29)

Suppression can also be realized via nominalization where the underlined words 'inquiry', 'charges' and 'arrest' function as nominals and lead to the exclusion of social actors.

-An inquiry, one that looks into the events that led up to the attack on 15 March, will occur (36)

-other charges will follow (41)

-The arrest itself was nothing short of an act of bravery (15)

Suppression can occur by deleting beneficiaries, for example:

-We wish to do more (59), you are able to pass on the support that is needed (31)

The beneficiaries (i.e., Muslims) are deleted.

\section{Backgrounding}

Ardern backgrounds, de-emphasizes, the social actors, by pushing them away from the focus of her addressees, when she declares upcoming decisions and measures. The backgrounded social actors in the following examples mainly refer to the official bodies in charge. Her focus is to foreground the measures taken and to declare the government's prompt action in such crisis. To assure the Muslim community that justice will take place and deny any racist stance against them.

-As I have already said Mr. Speaker our gun laws will change (38)

- These decisions will be announced (39)

- We do need to ensure that vigilance is maintained (26)

-Our security and intelligence services are receiving a range of additional information. As has been the case in the past, these $\underline{\text { are }}$ being taken extremely seriously, and they are being followed up.

\subsubsection{Inclusion}

\section{1) Role Allocation}

van Leeuwen (2008) discusses two roles of social actors in representation: the activated and the passivated roles. 
Abeer Aly El Attar

Table 2. Representational strategies of activation/passivation

\begin{tabular}{|l|l|l|l|}
\hline & Social actors & activation & passivation \\
\hline $\mathbf{1}$ & Ardern (I) & $\begin{array}{l}\text { I never anticipated } \\
\text { and hoped, I wanted }\end{array}$ & \\
\hline $\mathbf{2}$ & $\begin{array}{l}\text { Muslims( families, } \\
\text { Muslim community, } \\
\text { family members, } \\
\text { Victims) }\end{array}$ & $\begin{array}{l}\text { who } \\
\text { worshipping, Abdul } \\
\text { Aziz confronted, he } \\
\text { risked }\end{array}$ & $\begin{array}{l}\text { you, many, } \\
\text { victims }\end{array}$ \\
\hline $\mathbf{3}$ & perpetrator & $\begin{array}{l}\text { a man stormed, the } \\
\text { offender was shooting }\end{array}$ & $\begin{array}{l}\text {...rushing at the } \\
\text { terrorist }\end{array}$ \\
\hline $\mathbf{4}$ & New Zealanders & we surround you & \\
\hline $\mathbf{5}$ & $\begin{array}{l}\text { official bodies (cabinet, } \\
\text { Mr. Speaker, Members } \\
\text { of House, services) }\end{array}$ & $\begin{array}{l}\text { we mourn them } \\
\text { we feel he have moved } \\
\text { we } \\
\text { quickly }\end{array}$ & \\
\hline $\mathbf{6}$ & $\begin{array}{l}\text { responders(police } \\
\text { officers, ambulance } \\
\text { staff, health } \\
\text { professionals }\end{array}$ & $\begin{array}{l}\text { they showed, two } \\
\text { country police } \\
\text { officers rammed } \\
\text { ambulance }\end{array}$ & \\
\hline
\end{tabular}

\section{Activation}

All social actors were activated as the dynamic participants undergoing the activity; they are held responsible for their acts. Social actors are foregrounded and their roles are explicitly stated.

-A man stormed into a place of peaceful worship (4)

- Two country police officers rammed the vehicle (15)

-The images of the ambulance staff transporting victims (21)

Activation is realized by transitivity structures such as verbal processes (e.g. But he will when I speak be nameless) (I have said many times), mental processes (e.g. we feel the need), (we acknowledge you), (We cannot know your grief) and relational processes (our hearts are heavy). The active role is realized through circumstantialization by prepositional circumstantial with from.

- Solidarity that we are receiving from our friends all around the world (51). 'Our' refers to 'us, New Zealanders.

- Our language service has also provided support from than 5000 contacts $(31)$

Postmodification :

- A man ...took away the lives of 50 people (4)

- One of the roles I never anticipated having, and hoped never to have, is to voice the grief of a nation (11) 
- to securing the care of those affected (12)

' $\boldsymbol{O} \boldsymbol{f}$ 'nominalization realizes activation of the social actor referring to 'victims' in (4) and (12), and to 'New Zealanders in (11). Possessivation, using possessive pronouns, can activate a social actor, for example, 'our Muslim community', 'our gun laws', 'our doors', 'our friends', 'our partners'.

Passivation is divided into subjected social actors or beneficialized social actors. Social actors are represented as subjected to the activity when the actor functions as a goal in material process. Examples:

- We can walk with you at every stage (13)

- He risked his life and no doubt saved many (19)

- Ambulance staff transporting victims to Christchurch hospital (21)

- He lost his life trying to save those who were worshipping alongside him (18)

The passivated social actor 'victims' in the previous example is represented as the subjected social actor and the goal in a material process (i.e. walk with, saved, transporting, save). Subjection of passivated social actors is also realized by using against as a circumstantial element. The social actors represent 'victims'. For example: there is one person at the centre of this act of terror against our Muslim community (40)

Concerning the perpetrator of the shooting, he is referred to as the subjected passivated social actor as in the following examples:

- Naeem Rashid rushed and died after rushing at the terrorist and trying to wrestle the gun from him (18)

\section{2) Genericization and Specification}

Table 3. Representational strategy of Genericization/Specification

\begin{tabular}{|c|c|c|c|}
\hline & Social actors & Genericization & Specification \\
\hline 1 & Ardern $(\mathrm{I})$ & & \\
\hline 2 & $\begin{array}{l}\text { Muslims( families, Muslim } \\
\text { community, family } \\
\text { members, victims) }\end{array}$ & $\begin{array}{l}\text { families, Muslim } \\
\text { community, victims }\end{array}$ & $\begin{array}{l}\text { Naeem } \\
\text { Rashid, } \\
\text { Abdul Aziz, } \\
\text { Hati } \\
\text { Mohemmed } \\
\text { Daoud, the } \\
\text { 71-year-old } \\
\text { man }\end{array}$ \\
\hline 3 & perpetrator & $\begin{array}{l}\text { a man, a person, the } \\
\text { person, an Australian }\end{array}$ & \\
\hline
\end{tabular}




\begin{tabular}{|c|c|c|c|}
\hline \multicolumn{4}{|c|}{ Abeer Aly El Attar } \\
\hline & & $\begin{array}{l}\text { citizen, a } 28 \text {-year-old } \\
\text { man, a terrorist, a } \\
\text { criminal, an extremist }\end{array}$ & \\
\hline 4 & New Zealanders & & \\
\hline 5 & $\begin{array}{l}\text { official bodies (cabinet, } \\
\text { Mr. Speaker, Members of } \\
\text { House) }\end{array}$ & & \\
\hline 6 & $\begin{array}{l}\text { responders(police officers, } \\
\text { ambulance staff, health } \\
\text { professionals }\end{array}$ & responders, the police & $\begin{array}{l}\text { police, } \\
\text { ambulance } \\
\text { staff }\end{array}$ \\
\hline
\end{tabular}

The underlined words refer to 'Muslims'; they are referred to generically to represent them as a homogeneous group.

- ensuring the needs of families are met (28)

-Members of the Muslim community will gather (65)

- He was a member of a faith (56)

On the other hand, Muslim victims are presented as specific identifiable social actors to prompt the addressees to sympathize and feel empathy with them, for example:

- Naeem Rashid, originally from Pakistan, died after rushing at the terrorist....(18)

-Abdul Aziz, originally from Afghanistan, confronted and faced down the armed

terrorist...(19)

-He was the 71-year old man who opened the door at the Al-Noor mosque...(55)

By naming the victims, they are individualized and thus brought closer to the addressees (i.e. to everyone). Such representational strategy serves to align Muslims as ingroup. Despite her attempts to express solidarity and deny any racist stance in her parliamentary speech, Ardern reflects the 'otherness' of 'Muslims' by representing them as a generic type.

On the other, hand the perpetrator of the crime is another social actor who is presented as a generic type; he is backgrounded and anonymised; and he is negatively evaluated. By avoiding specification, Ardern prompts her addressees to avoid giving him the notoriety he sought, by never mentioning his name. Thus, she is emphasizing his "otherness" despite being an Australian citizen. He is to be ostracized.

-On a quiet Friday afternoon a man stormed into a place of peaceful worship (4) 
The Representation of Social Actors in Jacinda Ardern's Parliamentary

Speech: A Critical Discourse Analysis of New Zealand Mosque Massacre

- the man who took them (46)

The responders (government agents) are specified in terms of mass nouns and their action is presented in the past tense.

- Police were on the scene (14), police will be in the vicinity (27)

- The images of ambulance staff transporting victims (21)

3) Assimilation (aggregation and collectivization)

Table 4. Representational strategy of Assimilation

\begin{tabular}{|c|c|c|c|}
\hline & Social actors & $\begin{array}{l}\text { Aggregatio } \\
\text { n }\end{array}$ & Collectivization \\
\hline 1 & Ardern (I ) & & \\
\hline 2 & $\begin{array}{l}\text { Muslims (families, } \\
\text { Muslim community, } \\
\text { family members, victims) }\end{array}$ & 50 people & $\begin{array}{l}\text { they, Muslim } \\
\text { community, families, } \\
\text { the families of the } \\
\text { fallen, brothers, } \\
\text { daughters } \\
\text { victims }\end{array}$ \\
\hline 3 & Perpetrator & & \\
\hline 4 & New Zealanders & & $\begin{array}{l}\text { we (12 times), new } \\
\text { Zealand ,a nation( } 6 \\
\text { times) }\end{array}$ \\
\hline$\overline{5}$ & $\begin{array}{l}\text { official bodies (cabinet, } \\
\text { Mr. Speaker, Members of } \\
\text { House) }\end{array}$ & & we (34 times) \\
\hline 6 & $\begin{array}{l}\text { responders (police } \\
\text { officers, ambulance staff, } \\
\text { health professionals }\end{array}$ & & police, the police \\
\hline
\end{tabular}

The social actor "victims" is aggregated by using a definite quantifier '50 people'. In terms of collectivization, 'we', as a first -person plural pronoun is extensively used by Ardern to refer to official bodies (34 times) and to refer to New Zealanders as social actors (12 times). The social actor 'a nation' is collectivized to refer to New Zealanders (6 times). The social actor 'Muslims' is collectivized as Muslim community (6 times), families (4 times), brothers, daughters; they are represented through a process of collectivization as the victimized group who deserves empathy.

Examples for 'we' referring to official bodies:

- We have moved quickly to ensure that this includes repatriation (29) 


\section{Abeer Aly El Attar}

- Before we meet again next Monday, these decisions will be announced (39)

- We open our door to others and say welcome (57)

- We wish for every member of our communities to feel safe (60) Examples of 'we' referring to New Zealanders:

- We as a nation we mourn them (9)

- And we will, surround you with aroha, manaakitanga and all that makes us (13)

(Aroha means love; manaakitanga means care)

Examples of 'Muslim community' as social actors

-We wish to provide every comfort we can to our Muslim community (59)

- Mr. Speaker, if you'll allow, I'd like......to ensure the safety of our Muslim community (24)

\section{4) Association and Disassociation}

Only one instance of association occurs in Ardern's speech when she refers to the victims as the loved ones three times. "Brothers, daughters, fathers, and children' are associated to form 'loved ones'; 'loved ones' represent the 'victims'. The 'Muslims' form a group via association.

- Those loved ones, were brothers, daughters, fathers and children (7)

Association is also realized by "circumstances of accompaniment", for example:

- We too also stand with Christchurch (52), We stand with them (51)

- The global Muslim community who have stood with us (51)

This reveals incorporating Muslims as self and expressing solidarity.

\section{5) Indetermination and Differentiation}

Table. 5 Representational strategies of indetermination/ differentiation

\begin{tabular}{|l|l|l|l|}
\hline & Social actors & Indetermination & Differentiation \\
\hline 1 & Ardern (I) & & them (5 times) \\
\hline 2 & $\begin{array}{l}\text { Muslims( families, } \\
\text { Muslim community, } \\
\text { family members, } \\
\text { Victims) }\end{array}$ & each & $\begin{array}{l}\text { a man , one } \\
\text { person, the } \\
\text { person }\end{array}$ \\
\hline 3 & perpetrator & one, many & others, we, us \\
\hline 4 & New Zealanders & & \\
\hline
\end{tabular}




\begin{tabular}{|l|l|l|l|}
\hline 5 & $\begin{array}{l}\text { official bodies } \\
\text { (cabinet, } \\
\text { Mr. Speaker, Members } \\
\text { of House) }\end{array}$ & one, many & we \\
\hline 6 & $\begin{array}{l}\text { responders(police } \\
\text { officers, ambulance } \\
\text { staff, health } \\
\text { professionals }\end{array}$ & & \\
\hline
\end{tabular}

The perpetrator of the massacre is unspecified and anonymous. The representation strategy of indetermination is used to individually refer to him as 'a man', 'one person', and the person'; his identity is anonymised to distance him from New Zealand people. Eventually, Ardern attempts to align her audience against him.

- Yes, the person who committed these acts was not from here (58).

Ardern represents social actors (i.e., New Zealanders) using the strategy of indetermination, as in the following examples:

- Every single one of us has the power to change that (63)

- But to each we acknowledge you in this place (16)

Indetermination can be aggregated by using indefinite quantifiers, as follows:

- For many of us the first sign of the scale of this terrorist attack (21)

Concerning differentiation, 'them' is used 5 times to refer to 'victims' as (the other); 'us' occurs 14 times referring to New Zealanders (self). However, such differentiation does not reveal any concealed racism towards 'Muslims'. On the contrary, understanding, respect, and appreciation mark such dichotomy between us and them.

- And because they are us, we, as a nation, we mourn them (9).

- And we are grateful to the global Muslim community who have stood with us and we stand with them (51).

Another example of differentiation in Ardern's speech is differentiating between the perpetrator (the other) and the inclusive 'we', i.e. all the New Zealanders including the official bodies (the self).

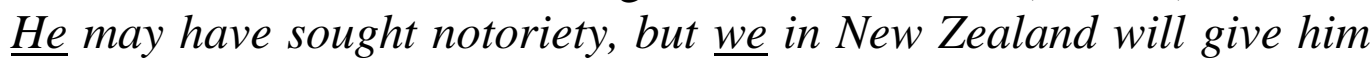
nothing (47)

He is not considered in-group or 'self'; he is different (i.e. the other). Ardern reiterates this idea by adopting a stance and calling upon the 


\section{Abeer Aly El Attar}

others (the New Zealanders, official bodies, Muslims), i.e. everyone to act likewise.

-But he will when_I speak, be nameless (45). And to the others, I implore you speak the names of those who were lost, rather than the man who took them (46).

6) Nomination and categorization

Table 6. Representational strategies of nomination/categorization

\begin{tabular}{|l|l|l|l|}
\hline & Social actors & Nomination & categorization \\
\hline 1 & Ardern & & \\
\hline 2 & $\begin{array}{l}\text { Muslims ( families, } \\
\text { Muslim community, } \\
\text { family members, victims) }\end{array}$ & $\begin{array}{l}\text { Naeem Rashid } \\
\text { Abdul Aziz } \\
\text { Hati Mohemmed } \\
\text { Daoud }\end{array}$ & \\
\hline 3 & perpetrator & & \\
\hline 4 & New Zealanders & & \\
\hline 5 & $\begin{array}{l}\text { official bodies (cabinet, } \\
\text { Mr. Speaker, Members of } \\
\text { House) }\end{array}$ & $\begin{array}{l}\text { Mr. Speaker (13 } \\
\text { times) }\end{array}$ & \\
\hline 6 & $\begin{array}{l}\text { responders(police officers, } \\
\text { ambulance staff, health } \\
\text { professionals }\end{array}$ & & \\
\hline
\end{tabular}

The victims are nominated to arouse the empathy of the addressees, and incorporate them as 'self'; whereas the perpetrator is not nominated (e.g. a man); thus, he is anonymised. Absence of such nomination is significant in CDA. Van Leeuwen (2008) argues that "nameless characters fulfill only passing, functional roles and do not become points of identification for the reader or listener" (p. 40). Ardern uses a titulated nomination (Mr. Speaker), as a vocative, in terms of a standard title 'Mr.'.

7) Functionalization and Identification

Table 7. Representational strategies of

functinalization/identification

\begin{tabular}{|c|c|c|c|}
\hline & Social actors & Functionalization & Identification \\
\hline 1 & Ardern (I) & & \\
\hline 2 & $\begin{array}{l}\text { Muslims( families, } \\
\text { Muslim community, } \\
\text { family members, } \\
\text { Victims) }\end{array}$ & & $\begin{array}{l}\text { family members, } \\
\text { their / our Muslim } \\
\text { community, its } \\
\text { members, their } \\
\text { loved ones, }\end{array}$ \\
\hline
\end{tabular}




\begin{tabular}{|l|l|l|l|}
\hline & & & $\begin{array}{l}\text { brothers } \\
\text {,aughters, } \\
\text { fathers, children, } \\
\text { the 71-year-old } \\
\text { man }\end{array}$ \\
\hline 3 & perpetrator & $\begin{array}{l}\text { the offender, } \\
\text { terrorist, criminal , } \\
\text { extremist }\end{array}$ & $\begin{array}{l}\text { Australian citizen, } \\
\text { a } \\
\text { man }\end{array}$ \\
\hline 4 & New Zealanders old \\
\hline 5 & $\begin{array}{l}\text { official bodies (cabinet, } \\
\text { Mr. Speaker, Members } \\
\text { of House) }\end{array}$ & $\begin{array}{l}\text { Mr. Speaker (13 } \\
\text { times) }\end{array}$ & $\begin{array}{l}\text { New Zealanders, } \\
\text { our communities }\end{array}$ \\
\hline 6 & $\begin{array}{l}\text { responders(police } \\
\text { officers, ambulance } \\
\text { staff, health } \\
\text { professionals }\end{array}$ & $\begin{array}{l}\text { police officers, } \\
\text { responders, health } \\
\text { professionals, } \\
\text { ambulance staff, } \\
\text { postman, } \\
\text { Publisher, }\end{array}$ \\
\hline
\end{tabular}

Concerning functionalization, the perpetrator as a social actor is functionalized as a criminal, a terrorist, an offender, and an extremist; hence, he is negatively appraised. For example, the offender was still shooting (15). Ardern uses pejorative functionalization. She refuses to mention the name of the perpetrator who shot the 50 Muslims; she keeps him nameless to the extent of distancing him from herself and New Zealand community at large. The perpetrator is dehumanised by referring to him with functionalizations that define only what he did (his role). 'Mr. Speaker' is a functionalized social actor; all responders are functionalized social actors. Ardern is stressing that each and every one played his role efficiently in this crisis. For that reason, "functionalization can sound more official" (Machin\& Mayr, 2012, p. 81). Thus, official bodies and responders as social actors are mainly functionalized.

Concerning identification, the perpetrator is classified by provenance (an Australian citizen) and age (a 28- year- old man); he is never identified by his name. The victims are classified by religion (Muslim) Ardern uses 'our Muslim community' three times in her speech, trying to represent Muslims as part of New Zealand's society. This marks a possessivated relational identification which indicates "belonging together" (van Leeuwen, 2008, p.43). 'Our' as a possessive pronoun 


\section{Abeer Aly El Attar}

creates a sense of belonging to a group, constructs a positive image of Ardern, as a Prime Minister, and the official bodies as caring and concerned. Another example of possessivated relational identification is "their loved ones", which occurs twice in Arden's speech. 'Their loved ones' refers to the victims. The pronoun 'their' reflects group affiliation whereby Muslims and their victims construct one group. It can be deduced that 'Muslims' are mainly represented on the basis of relational identity. Relational identification can "align the victim with the Self and contribute to the construction of a delegitimated Other" (Hart, 2016, p.36).

-Any family members who would like to move their loved ones away from New Zealand (29)

\section{8) Personalization and Impersonalization}

Social actors are personalized via personal pronouns, possessive pronouns, proper names, and nouns. Thus, personalization serves to identify social actors.

Table 8. Representational strategies of personalization/ impersonalization

\begin{tabular}{|c|c|c|c|c|}
\hline & \multirow[t]{2}{*}{ Social actors } & \multirow[t]{2}{*}{ personalization } & \multicolumn{2}{|c|}{ impersonalization } \\
\hline & & & Abstraction & objectivation \\
\hline 1 & Ardern (I) & I (19 instances) & & \\
\hline 2 & $\begin{array}{l}\text { Muslims( } \\
\text { families, } \\
\text { Muslim } \\
\text { community, } \\
\text { family } \\
\text { members, } \\
\text { Victims) }\end{array}$ & $\begin{array}{l}\text { They, you, he, } \\
\text { their, our } \\
\text { Muslim } \\
\text { community, } \\
\text { loved ones, } \\
\text { Naeem Rashid, } \\
\text { Abdul Aziz, Hati } \\
\text { Mohemmed } \\
\text { Daoud, }\end{array}$ & & \\
\hline 3 & perpetrator & he, his name & & $\begin{array}{l}\text { his vehicle, } \\
\text { his car door, } \\
\text { the gun }\end{array}$ \\
\hline 4 & $\begin{array}{l}\text { New } \\
\text { Zealanders }\end{array}$ & we, you & & $\begin{array}{l}\text { our spirit, our } \\
\text { hearts }\end{array}$ \\
\hline 5 & $\begin{array}{l}\text { official bodies } \\
\text { (cabinet, } \\
\text { Mr. Speaker, } \\
\text { Members of } \\
\text { House, }\end{array}$ & $\begin{array}{l}\text { we, you, our gun } \\
\text { laws }\end{array}$ & $\begin{array}{ll}\text { cabinet, a } \\
\text { nation } \\
\text { language } \\
\text { service, } \\
\text { support }\end{array}$ & \\
\hline
\end{tabular}




\begin{tabular}{|l|l|l|l|l|}
\hline & services) & & \\
\hline 6 & $\begin{array}{l}\text { responders(pol } \\
\text { ice officers, } \\
\text { ambulance } \\
\text { staff, health } \\
\text { professionals }\end{array}$ & $\begin{array}{l}\text { They ,them ,your } \\
\text { work, their acts } \\
\text { presence }\end{array}$ & $\begin{array}{l}\text { security } \\
\text { presence }\end{array}$ & \\
\hline
\end{tabular}

- I know that as a nation we wish to provide every comfort we can (59)

- Our language service has also provided support (31)

The impersonalizations of official bodies and responders are abstractions; where the focus is on their performance during and after the attack. Somatization, a type of objectivation, occurs in relation to "New Zealanders" to reflect their emotional involvement (e.g. our spirit, our hearts). The perpetrator of the massacre is impersonalized via instrumentalization (e.g. Two country police officers rammed his vehicle; they pulled open his car door; trying to wrestle the gun from him; there were explosives inside).

\subsection{Van Dijk's ideological square}

The analysis applying van Dijk's $(1997,1998,2006,2009,2011)$ concept proves there could be another strategy that became evident in Ardern's speech: Positive Other- presentation, in addition to Van Dijk's two other categories: Positive Self- Presentation and Negative Other- Presentation. Such classification agrees with Attia's (2002) findings of broadening Van Dijk's square to incorporate two more strategies: Negative Self- presentation and Positive Otherpresentation. In her concluding utterance, Ardern expresses solidarity and shows acceptance of Muslims by explicitly saying (we are one, they are us), whereby they are positively evaluated and aligned as ingroup. However, their 'otherness' is always emphasized throughout her speech in terms of the pronouns (They/Them vs. We/Us). Such dichotomy is not racially biased as she positively presents them as outgroup.

She presents New Zealanders (people, Ardern herself, and all concerned bodies) as self, so they are positively evaluated; she presents the perpetrator as other, so he is negatively evaluated. However, the elusive pronoun we can sometimes refer to the whole 


\section{Abeer Aly El Attar}

country (i.e. New Zealand), or it can refer to the speaker (Ardern), the audience/addressees, other hearers (party members, supporters, official bodies). For that reason, we, as an elusive pronoun, allows several interpretations according to the intended referents. The following table provides examples from the speech to clarify the three strategies.

Table 9: The pronouns that reflect the three strategies of self and other-presentation

\begin{tabular}{|c|c|c|c|}
\hline us 14 times & $\begin{array}{l}\text { we } \quad(\quad 46 \\
\text { times })\end{array}$ & we & our \\
\hline $\begin{array}{l}\text {-They are us } \\
\text {-we will surround you with } \\
\text { aroha, manoakitanga and all } \\
\text { that makes us, us } \\
\text {-let us acknowledge their } \\
\text { grief } \\
\text {-please accept the heartfelt } \\
\text { thanks of us all } \\
\text {-every single one of us has } \\
\text { the power to change that } \\
\text {-we are grateful to the global } \\
\text { Muslim community who } \\
\text { stood with us }\end{array}$ & $\begin{array}{l}\text {-we stand } \\
\text { with them } \\
\text {-we are } \\
\text { working to } \\
\text { provide } \\
\text {-we mourn } \\
\text {-we will } \\
\text { examine } \\
\text {-we feel } \\
\text {-we cannot } \\
\text { allow this to } \\
\text { happen } \\
\text {-we } \\
\text { surround } \\
\text {-we will } \\
\text { collectively } \\
\text { find } \\
\text {-we } \\
\text {-we } \\
\text { with } \\
\text { Christchurch } \\
\text {-we } \\
\text { deeply and } \\
\text { grateful } \\
\text { we are } \\
\text { nation a } \\
\text { we } \\
\text { acknowledge } \\
\text { you open our } \\
\text { doors }\end{array}$ & $\begin{array}{l}\text {-we are proud } \\
\text { of } \\
\text {-we maintain } \\
\text { vigilance } \\
\text {-we wish to do } \\
\text { more } \\
\text {-we do remain } \\
\text { on high alert } \\
\text {-we have } \\
\text { moved quickly } \\
\text {-we wish to } \\
\text { provide every } \\
\text { comfort }\end{array}$ & $\begin{array}{l}\text { provide comfort to } \\
\text { our Muslim } \\
\text { community } \\
\text { our communities } \\
\text { our collective } \\
\text { memories } \\
\text { our hearts are } \\
\text { heavy } \\
\text { our spirit is strong } \\
\text { our guns laws }\end{array}$ \\
\hline
\end{tabular}


The Representation of Social Actors in Jacinda Ardern's Parliamentary

Speech: A Critical Discourse Analysis of New Zealand Mosque Massacre

\begin{tabular}{|c|c|c|c|c|}
\hline $\begin{array}{l}\text { they } \\
\text { (Muslims) }\end{array}$ & $\begin{array}{l}\text { their } \\
\text { (Muslims) }\end{array}$ & $\begin{array}{l}\text { Them } \\
\text { (Muslims) }\end{array}$ & $\begin{array}{c}\text { he (perpetrator) } \\
7 \text { times }\end{array}$ & him \\
\hline $\begin{array}{l}\text {-they were } \\
\text { New } \\
\text { Zealanders } \\
\text {-they are us } \\
\text { (3 times) } \\
\text {-let's support } \\
\text { them as they } \\
\text { gather again } \\
\text { for worship } \\
\text {-they can } \\
\text { attend } \\
\text { funerals }\end{array}$ & $\begin{array}{l}\text { their Muslim } \\
\text { faith } \\
\text { their loved } \\
\text { ones } \\
\text { their grief } \\
\text { their Muslim } \\
\text { community }\end{array}$ & $\begin{array}{l}\text { mourn them } \\
\text { care to them } \\
\text { support them } \\
\text { stand with } \\
\text { them } \\
\text { the man who } \\
\text { took them }\end{array}$ & $\begin{array}{l}\text { he is a terrorist } \\
\text { he is a criminal } \\
\text { he will be } \\
\text { nameless } \\
\text { he was not } \\
\text { raised here } \\
\text { he is an } \\
\text { extremist } \\
\text { he will face the } \\
\text { full force of the } \\
\text { law }\end{array}$ & $\begin{array}{l}\text {-New Zealand will } \\
\text { give him nothing } \\
\text {-trying to wrestle } \\
\text { the gun from him } \\
\text { - pulled him out }\end{array}$ \\
\hline
\end{tabular}

It is evident from the table that the Muslims are positively presented as other in terms of the personal pronouns 'they' and 'them' (e.g. support them, provide comfort, they are us, etc.). The perpetrator is negatively presented as other (outgroup) in terms of the pronoun he (criminal, terrorist, racist, etc.); the perpetrator is ostracized and dehumanized. The New Zealanders are positively presented as self (provide comfort, we open our doors, we are grateful, they are us, etc.). The New Zealanders are portrayed as supportive, caring; they are simply humanized. Ardern presents the official bodies as competent, alert, responsible and just. The Muslims are presented as the victimized group, who deserve care and support; they are appreciated and humanized. For that reason, they are classified as New Zealanders (e.g. they were New Zealanders, they are us). Muslims are accepted as part of New Zealand Community (e.g. our Muslim community); the possessive pronoun 'our' is used to imply solidarity, alliances, and political positions, as van Dijk (1997) explains. As a competent politician Ardern manipulates the use of pronouns to draw a line between the perpetrator and the New Zealanders; she draws an unbiased line between Us and Them, as Muslims are positively presented. 


\section{Abeer Aly El Attar}

\section{Findings}

The six social actors and the representational strategies are represented as presented in the following table:

Table 10. The results of representational strategies of social actors

\begin{tabular}{|c|c|c|c|c|c|c|}
\hline $\begin{array}{l}\text { represen } \\
\text { tational } \\
\text { strategie } \\
\text { s }\end{array}$ & $\begin{array}{l}\text { suppr } \\
\text { ession }\end{array}$ & $\begin{array}{l}\text { backgro } \\
\text { unding }\end{array}$ & $\begin{array}{l}\text { activatio } \\
\text { n }\end{array}$ & $\begin{array}{l}\text { passiv } \\
\text { ation }\end{array}$ & $\begin{array}{l}\text { generici } \\
\text { zation }\end{array}$ & $\begin{array}{l}\text { specifica } \\
\text { tion }\end{array}$ \\
\hline Ardern & $\sqrt{ }$ & & $\sqrt{ }$ & & & \\
\hline $\begin{array}{l}\text { perpetrat } \\
\text { or }\end{array}$ & $\sqrt{ }$ & & $\sqrt{ }$ & $\sqrt{ }$ & $\sqrt{ }$ & \\
\hline Muslims & & & $\sqrt{ }$ & $\sqrt{ }$ & $\sqrt{ }$ & $\sqrt{ }$ \\
\hline $\begin{array}{l}\text { New } \\
\text { Zealande } \\
\text { rs }\end{array}$ & & & $\sqrt{ }$ & & & \\
\hline $\begin{array}{l}\text { official } \\
\text { bodies }\end{array}$ & $\sqrt{ }$ & $\sqrt{ }$ & $\sqrt{ }$ & & & \\
\hline $\begin{array}{l}\text { Respond } \\
\text { ers }\end{array}$ & & & $\sqrt{ }$ & & $\sqrt{ }$ & \\
\hline $\begin{array}{c}\text { represen } \\
\text { tational } \\
\text { strategie } \\
\text { s }\end{array}$ & $\begin{array}{l}\text { aggre } \\
\text { gation }\end{array}$ & $\begin{array}{l}\text { collectiv } \\
\text { ization }\end{array}$ & $\begin{array}{l}\text { associati } \\
\text { on }\end{array}$ & $\begin{array}{l}\text { disasso } \\
\text { ciation }\end{array}$ & $\begin{array}{l}\text { indeter } \\
\text { minatio } \\
\text { n }\end{array}$ & $\begin{array}{l}\text { different } \\
\text { iation }\end{array}$ \\
\hline \multicolumn{7}{|l|}{ Ardern } \\
\hline $\begin{array}{l}\text { perpetrat } \\
\text { or }\end{array}$ & & & & & $\sqrt{ }$ & $\sqrt{ }$ \\
\hline Muslims & $\sqrt{ }$ & $\sqrt{ }$ & $\sqrt{ }$ & & & $\sqrt{ }$ \\
\hline $\begin{array}{l}\text { New } \\
\text { Zealande } \\
\text { rs }\end{array}$ & & $\sqrt{ }$ & & & & $\sqrt{ }$ \\
\hline $\begin{array}{l}\text { official } \\
\text { bodies }\end{array}$ & & $\sqrt{ }$ & & & & $\sqrt{ }$ \\
\hline $\begin{array}{l}\text { Respond } \\
\text { ers }\end{array}$ & & $\sqrt{ }$ & & & & \\
\hline $\begin{array}{l}\text { represen } \\
\text { tational } \\
\text { strategie } \\
\text { S }\end{array}$ & $\begin{array}{l}\text { nomin } \\
\text { ation }\end{array}$ & $\begin{array}{l}\text { categori } \\
\text { zation }\end{array}$ & $\begin{array}{l}\text { function } \\
\text { alization }\end{array}$ & $\begin{array}{l}\text { identif } \\
\text { ication }\end{array}$ & $\begin{array}{l}\text { persona } \\
\text { lization }\end{array}$ & $\begin{array}{l}\text { imperso } \\
\text { nalizatio } \\
\text { n }\end{array}$ \\
\hline Ardern & & & & & $\sqrt{ }$ & \\
\hline $\begin{array}{l}\text { perpetrat } \\
\text { or }\end{array}$ & & & $\sqrt{ }$ & & $\sqrt{ }$ & $\sqrt{ }$ \\
\hline
\end{tabular}


The Representation of Social Actors in Jacinda Ardern's Parliamentary

Speech: A Critical Discourse Analysis of New Zealand Mosque Massacre

\begin{tabular}{|l|l|l|l|l|l|l|}
\hline Muslims & $\sqrt{ }$ & & & $\sqrt{ }$ & $\sqrt{ }$ & \\
\hline $\begin{array}{l}\text { New } \\
\text { Zealande } \\
\text { rs }\end{array}$ & & & & & $\sqrt{ }$ & $\sqrt{ }$ \\
\hline $\begin{array}{l}\text { official } \\
\text { bodies }\end{array}$ & $\sqrt{ }$ & & $\sqrt{ }$ & & $\sqrt{ }$ & $\sqrt{ }$ \\
\hline $\begin{array}{l}\text { Respond } \\
\text { ers }\end{array}$ & & & $\sqrt{ }$ & & $\sqrt{ }$ & \\
\hline
\end{tabular}

\section{1) Ardern}

As a social actor, Arden is represented as a suppressed excluded social actor through passive agent deletion for the sake of foregrounding the measures taken by official bodies, including herself as a responsible member. Her focus is to foreground the prompt measures taken to aid the Muslim community, to deny any racist stance against them, and to stress the policy of equality in rights among citizens. She uses the pronoun 'we', incorporating herself with the New Zealanders, as collectivized social actors. She also personalizes herself as a speaker and enacts her role as a Prime Minister at the same time. She presents herself via activation, as an activated social actor; thus, underlining her awareness and competency in handling the crisis.

\section{2) The perpetrator}

As a social actor, he has been suppressed through nominalization (charges, arrest). He is genericised, activated, and foregrounded to emphasize his responsibility for the attack. He is represented as anonymised social actor who is negatively appraised and functionalized as a (terrorist, criminal, offender, extremist). He is not nominated, nor categorized to keep him nameless and ostracize him as (other). He is only identified by provenance as an Australian citizen and by age as a young man. Concerning indetermination, the 'perpetrator' as a social actor is unspecified as 'a man', 'one person', 'the person'. He is impersonalized by means of instruementalization to frame him as a criminal and a terrorist. Hence, he is positioned as outgroup (the other) and distanced from New Zealanders. Ardern is against his racist ideology which is manifested in imbuing fear and inciting violence against Muslims, as he later confessed.

\section{3) Muslims}

This group of social actors is sympathetically treated and referred to generically as one group/ one type to stress their homogeneity. They are 


\section{Abeer Aly El Attar}

also collectivized and represented as a victimized group that deserves empathy and sympathy. The victims are specified and nominated by mentioning their names and their stories to sympathize with them. They are also aggregated by mentioning the number of dead people (e.g. 50 people). They are identified as 'Muslim community' and classified by religion as 'Muslim'. They are relationally identified and associated as a homogenous group that belongs together. However, they are differentiated as 'the other' through the use of the personal pronoun them. They were mainly personalized to identify them as social actors. Their activated social role marks them as dynamic social actors. They are also represented as subjected social actors.

It is evident that Ardern attempts to align the Muslims as a social group with 'the Self', i.e. New Zealand community, and to ostracize the perpetrator as "other'. However, the 'otherness' of Muslims is still reflected, but not from a racist stance. Their 'otherness' is hinted at and reflected via association, differentiation, relational identification, collectivization, and genercization.

\section{4) New Zealanders}

As social actors the New Zealanders are collectivized through the use of the personal pronoun 'we' and referred to as a 'nation'. They are represented as one group adopting a positive attitude towards 'Muslims'. They are identified by provenance as (New Zealanders) and possessivated relational identification "our community"; hence creating a sense of belonging. New Zealanders are personalized as social actors through the personal pronouns 'we' and 'you' and impersonalized through objectivation (our spirit, our hearts) to reflect their emotional involvement. They are represented as activated social actors through material process to foreground their care and sympathy. Differentiation as a representational strategy refers to New Zealanders as 'we', 'us', 'others'; however, such strategy does not mark any discrimination, rather understanding.

\section{5) Official bodies}

They are referred to as suppressed social actors because they could be easily retrieved from the speech. They are represented as responsible for all measures and action. They are also backgrounded. They are not referred to generically or specified; they are collectivized through using the personal pronoun 'we', where they function as one group exerting concerted effort to handle the situation. Ardern addresses and nominates 'Mr. Speaker' by using honorifics 'Mr.' Mr. Speaker is functionalized as a social actor. Official bodies are functionalized as they play an active role in relation to Muslims. Ardern uses the personal pronoun - inclusive 
The Representation of Social Actors in Jacinda Ardern's Parliamentary

Speech: A Critical Discourse Analysis of New Zealand Mosque Massacre

'we' to incorporate the official bodies, people, and herself in one group (self) and differentiate 'self' from 'other' (the perpetrator). She attempts to distance him from everyone.

\section{6) Responders}

They are represented as genericized, functionalized, activated social actors who are presented as responsible actors willing to perform their duty. They are referred to as collectivized social actors who concerted efforts to face the crisis and provide assistance.

\section{Conclusion}

Adopting van Leeuween's (2008) socio-semiotic framework proved useful in representing the social actors. The social actors are represented differently in Ardern' speech. Ardern, the official bodies and responders are referred to as activated and personalized social actors who promptly and competently played their roles. Muslims are nominated and identified in terms of relational identification to arouse the sympathy of New Zealanders. Muslims are represented as the victimized group; the perpetrator as an anonymous genericized social actor to ostracize him. Ardern managed to tailor such representations to suit her own ideology which she explicitly summed up in three words: They are us. She adopts an anti- racist stance by distancing herself, as a politician, and New Zealand's community as a whole from the perpetrator's ideology, and ostracizing him as 'other'. Van Dijk's ideological square can be broadened to incorporate a third strategy: Muslims are positively presented as 'other'. 


\section{Abeer Aly El Attar}

\section{References}

Ashmawi, G. A. (2011). The representation of Muslims in John Updike's

Terrorist: A critical discourse analysis. Philology, 55, 13-47.

Attia, M. F. (2002). Who is 'Us'? Who is 'Them'? Cultural conflict versus cultural Interaction. Philology, 38 (1), 128-161.

Bernard, T. (2018). The discursive representation of social actors in the corporate social

responsibility (CSR) and integrated annual (IA) reports of two South African Mining

companies. Critical Approaches to Discourse Analysis across Disciplines, 10 (1), $81-97$.

Chilton, P.\& Scaffner, C. (2011). In T. van Dijk (Ed.), Discourse studies: A multidisciplinary introduction (pp. 303- 330). London: Sage Publications Ltd.

Dashti, L. \& Mehrpour, S. (2017). Representation of Social Actors in J. Krishnamurti and Alan Watts' Philosophical Speeches: A Critical Discourse Analysis. Journal of Applied Linguistics and Language Research, 4(4), 51-59.

Fairclough, N. (1989). Language and Power. London: Longman.

Fairclough, N., Mulderrig, J., \& Wodak, R. (2011). Critical discourse analysis. In. T. van Dijk (Ed.), Discourse studies: A multidisciplinary introduction (pp.357378). London: Sage Publications Ltd.

Fairclough, N. \& Wodak, R. (1997). Critical discourse analysis. In T.van Dijk (Ed.), Discourse as interaction (pp. 258-285). London: Sage.

Halliday, M. A. K. \& Matthiessen, C. M. I. M. (2004). Introduction to functional grammar (3rd edition). London: Arnold.

Hart, C. (2016). Discourse, Grammar and ideology: Functional and cognitive perspectives. London and New York: Bloomsbury Academic.

Machin, D.\& Mayr, A. (2012). How to do critical discourse analysis: A multimodal introduction. London: Sage Publications.

Meyer, M. (2009). Between theory, method, and politics: Positioning of the approaches to CDA. In R.Wodak \& M. Meyer (Eds.), Methods of critical discourse analysis ( $2^{\text {nd }}$ ed.)(pp 14-31). London: Sage.

Rashidi, N. \& Souzandehfar, M. (2010). A critical discourse analysis of debates between Republicans and Democrats over the continuation of war in Iraq. JOLIE, 3, 55-82.

Sahragrad, R., \& Davatgarzadeh, G. (2010). The representation of social actors in Interchange Third Edition series: A critical discourse analysis. The Journal of Teaching Language Skills (JTLS), 2(1), 67-89. 
van Dijk, T. A. (1997). What is political discourse analysis? In J. Bloomaert \& C. Bulcaen (Eds.), Political linguistics (pp. 11-52). Amsterdam: John Benjamins.

\footnotetext{
(1998). Ideology: A multidisciplinary Approach. London: Sage.

(2005). Politics, Ideology, and discourse. Retreieved from http://www.discourses.org /download/articles/ (2006). Ideology and discourse analysis. Journal of Political Ideologies, 11(2), 115-140.
}

(2009). Multidisciplinary CDA: A plea for diversity. In R.Wodak \& M. Meyer (Eds.). Methods of critical discourse analysis ( $2^{\text {nd }}$ ed.) (pp 14-31). London: Sage.

(2011). Discourse and ideology. In T. van Dijk (Ed.), Discourse studies: A multidisciplinary introduction (pp. 379- 407). London: Sage Publications Ltd.

(2015). Critical discourse analysis. In D. Tannen, H. E. Hamilton, \& D. T. Schiffrin (Eds.), The handbook of discourse analysis( $\left(2^{\text {nd }} e d.\right)$ (pp.466-485). Oxford: Wiley Blackwell.

van Leeuwen, T. (1996). The representation of social actors in discourse. In C. Caldas \&M. Coulthard (Eds.), Texts and practices: Readings in critical discourse analysis (pp.32-70). London: Routledge.

van Leeuwen, T. (2008). Discourse and Practice: New Tools for Discourse Analysis. Oxford:

Oxford University Press.

Wilson,J. (2015). Political discourse. In D.Tannen, H. E. Hamilton \& D. Schiffrin (Eds.), The handbook of discourse analysis. ( $2^{\text {nd }}$ ed.) (pp.775- 794). Oxford: Wiley Blackwell.

Wodak,R. (2009). What CDA is about - a summary of its history, important concept and its developments. In R.Wodak \& M. Meyer (Eds.), Methods of critical discourse analysis ( $2^{\text {nd }}$ ed.) (pp.1-13). London: Sage.

\section{Websites}

www.tvnz.co.nz 


\section{Abeer Aly El Attar}

\section{Appendix}

Full statement: Jacinda Ardern addresses Parliament on Christchurch terror attack

https://www.tvnz.co.nz/one-news/new-zealand/full-statement-jacinda-ardernaddresses-parliament-christchurch-terror-attack

Prime Minister Jacinda Ardern addressed Parliament today on the Christchurch mosques terror attack, saying a quiet Friday afternoon has become our darkest of days, but that immediate measures have been put in place to ensure the safety of New Zealand's Muslim community and everyone.

\section{Here's the Prime Minister's full statement to the House:}

1) Mr Speaker,

2) Al salam Alaikum

3) Peace be upon you. And peace be upon all of us.

4) Mr Speaker the 15th of March will now forever be a day etched in our collective memories. On a quiet Friday afternoon a man stormed into a place of peaceful worship and took away the lives of 50 people.

5) That quiet Friday afternoon has become our darkest of days.

6) But for the families, it was more than that. It was the day that the simple act of prayer - of practising their Muslim faith and religion - led to the loss of their loved ones lives.

7) Those loved ones, were brothers, daughters, fathers and children.

8) They were New Zealanders. They are us.

9) And because they are us, we, as a nation, we mourn them.

10) We feel a huge duty of care to them. And Mr Speaker, we have so much we feel the need to say and to do.

11) One of the roles I never anticipated having, and hoped never to have, is to voice the grief of a nation.

12) At this time, it has been second only to securing the care of those affected, and the safety of everyone.

13) And in this role, I wanted to speak directly to the families. We cannot know your grief, but we can walk with you at every stage. We can. And we will, surround you with aroha, manakitanga and all that makes us, us. Our hearts are heavy but our spirit is strong.

14) Mr Speaker, 6 minutes after a 111 call was placed alerting the police to the shootings at Al-Noor mosque, police were on the scene.

15) The arrest itself was nothing short of an act of bravery. Two country police officers rammed the vehicle from which the offender was still shooting. They pulled open his car door, when there were explosives inside, and pulled him out.

16) I know we all wish to acknowledge that their acts put the safety of New Zealanders above their own, and we thank them.

17) But they were not the only ones who showed extraordinary courage. 
The Representation of Social Actors in Jacinda Ardern's Parliamentary

Speech: A Critical Discourse Analysis of New Zealand Mosque Massacre

18) Naeem Rashid, originally from Pakistan, died after rushing at the terrorist and trying to wrestle the gun from him. He lost his life trying to save those who were worshipping alongside him.

19) Abdul Aziz, originally from Afghanistan, confronted and faced down the armed terrorist after grabbing the nearest thing to hand - a simple eftpos machine. He risked his life and no doubt saved many with his selfless bravery.

20) There will be countless stories, some of which we may never know, but to each, we acknowledge you in this place, in this House.

21) For many of us the first sign of the scale of this terrorist attack was the images of ambulance staff transporting victims to Christchurch hospital.

22) To the first responders, the ambulance staff and the health professionals who have assisted - and who continue to assist those who have been injured.

23) Please accept the heartfelt thanks of us all. I saw first-hand your care and your professionalism in the face of extraordinary challenges. We are proud of your work, and incredibly grateful for it.

24) Mr Speaker, if you'll allow, I'd like to talk about some of the immediate measures currently in place especially to ensure the safety of our Muslim community, and more broadly the safety of everyone.

25) As a nation, we do remain on high alert. While there isn't a specific threat at present, we are maintaining vigilance.

26) Unfortunately, we have seen in countries that know the horrors of terrorism more than us, there is a pattern of increased tension and actions over the weeks that follow that means we do need to ensure that vigilance is maintained.

27) There is an additional and ongoing security presence in Christchurch, and as the police have indicated, there will continue to be a police presence at mosques around the country while their doors are open. When they are closed, police will be in the vicinity.

28) There is a huge focus on ensuring the needs of families are met. That has to be our priority. A community welfare centre has been set up near the hospital in Christchurch to make sure people know how to access support.

29) Visas for family members overseas are being prioritised so that they can attend funerals. Funeral costs are covered, and we have moved quickly to ensure that this includes repatriation costs for any family members who would like to move their loved ones away from New Zealand.

30) We are working to provide mental health and social support. The 1737 number yesterday received roughly 600 texts or phonecalls. They are on average lasting around 40 minutes, and I encourage anyone in need to reach out and use these services. They are there for you.

31) Our language service has also provided support from more than 5000 contacts, ensuring whether you are ACC or MSD, you are able to pass on 


\section{Abeer Aly El Attar}

the support that is needed, in the language that is needed. To all those working within this service, we say thank you.

32) Our security and intelligence services are receiving a range of additional information. As has been the case in the past, these are being taken extremely seriously, and they are being followed up.

33) I know though Mr Speaker, that there have rightly been questions around how this could have happened here. In a place that prides itself on being open, peaceful, diverse.

34) And there is anger that it has happened here.

35) There are many questions that need to be answered, and the assurance that I give you is that they will be.

36) Yesterday Cabinet agreed that an inquiry, one that looks into the events that led up to the attack on 15 March, will occur. We will examine what we did know, could have known, or should have known. We cannot allow this to happen again.

37) Part of ensuring the safety of New Zealanders must include a frank examination of our gun laws.

38) As I have already said Mr Speaker, our gun laws will change. Cabinet met yesterday and made in-principle decisions, 72 hours after the attack.

39) Before we meet again next Monday, these decisions will be announced.

40) Mr Speaker, there is one person at the centre of this act of terror against our Muslim community in New Zealand.

41) A 28-year-old man - an Australian citizen - has been charged with one count of murder. Other charges will follow. He will face the full force of the law in New Zealand. The families of the fallen will have justice.

42) He sought many things from his act of terror, but one was notoriety.

43) And that is why you will never hear me mention his name.

44) $\mathrm{He}$ is a terrorist. He is a criminal. He is an extremist.

45) But he will, when I speak, be nameless.

46) And to others I implore you: speak the names of those who were lost, rather than name of the man who took them.

47) He may have sought notoriety, but we in New Zealand will give him nothing. Not even his name.

48) Mr. Speaker, we will also look at the role social media played and what steps we can take, including on the international stage, and in unison with our partners.

49) There is no question that ideas and language of division and hate have existed for decades, but their form of distribution, the tools of organisation, they are new.

50) We cannot simply sit back and accept that these platforms just exist and that what is said on them is not the responsibility of the place where they are published. They are the publisher. Not just the postman. There cannot be a case of all profit no responsibility. This of course doesn't take away the responsibility we too must show as a nation, to confront racism, 
The Representation of Social Actors in Jacinda Ardern's Parliamentary

Speech: A Critical Discourse Analysis of New Zealand Mosque Massacre

violence and extremism. I don't have all of the answers now, but we must collectively find them. And we must act.

51) Mr. Speaker, we are deeply grateful for all messages of sympathy, support and solidarity that we are receiving from our friends all around the world. And we are grateful to the global Muslim community who have stood with us, and we stand with them.

52) Mr. Speaker, I acknowledge that we too also stand with Christchurch, in a devastating blow that this has been to their recovery. I acknowledge every member of this House that has stood alongside their Muslim community but especially those in Canterbury as we acknowledge this double grief

53) As I conclude I acknowledge there are many stories that will have struck all of us since the 15th of March.

54) One I wish to mention, is that of Hati Mohemmed Daoud Nabi.

55) He was the 71-year-old man who opened the door at the Al-Noor mosque and uttered the words 'Hello brother, welcome'. His final words.

56) Of course he had no idea of the hate that sat behind the door, but his welcome tells us so much - that he was a member of a faith that welcomed all its members, that showed openness, and care.

57) I have said many times Mr. Speaker, we are a nation of 200 ethnicities, 160 languages. We open our doors to others and say welcome. And the only thing that must change after the events of Friday, is that this same door must close on all of those who espouse hate and fear.

58) Yes the person who committed these acts was not from here. He was not raised here. He did not find his ideology here, but that is not to say that those very same views do not live here.

59) I know that as a nation, we wish to provide every comfort we can to our Muslim community in this darkest of times. And we are. The mountain of flowers around the country that lie at the doors of mosques, the spontaneous song outside the gates. These are ways of expressing an outpouring of love and empathy. But we wish to do more.

60) We wish for every member of our communities to also feel safe.

61) Safety means being free from the fear of violence.

62) But it also means being free from the fear of those sentiments of racism and hate, that create a place where violence can flourish.

63) And every single one of us has the power to change that.

64) Mr. Speaker on Friday it will be a week since the attack.

65) Members of the Muslim community will gather for worship on that day.

66) Let us acknowledge their grief as they do.

67) Let's support them as they gather again for worship.

68) We are one, they are us. 